\title{
Link between environmental anomalies, growth and condition of pilchard Sardina pilchardus larvae in the northwestern Mediterranean
}

\author{
Ignacio A. Catalán*, M. Pilar Olivar, Isabel Palomera, Elisa Berdalet \\ Institut de Ciències del Mar, CMIMA (CSIC), Pg. Marítim de la Barceloneta 37-49, CP 08003 Barcelona, Spain
}

\begin{abstract}
Relationships between environmental factors and the growth and condition of pilchard Sardina pilchardus (Walbaum) larvae were studied in November 1998 in the northwestern Mediterranean (NWM). Long-term growth of fish was assessed using otolith analysis and condition was assessed through histological and biochemical (RNA/DNA) indices. These measurements were conducted on larvae belonging to 2 station groups (A and B) previously defined through principal component analysis (PCA) on 7 environmental variables. Correlations between individual condition indices and environmental values at place of capture were also performed. Condition in environmental group A was significantly higher than in group B as assessed by both histological indices and RNA/DNA. Long-term growth, however, did not differ significantly between groups except for the otolith diameter vs. standard length (SL) relationship. The stations conforming to environmental group A were characterised by environmental ranges that would form a favorable habitat for larval success, including surface temperatures $<19^{\circ} \mathrm{C}$, relatively low stratification (maximum Brunt Väissälä, B-V, $<0.8$ cycles $\mathrm{h}^{-1}$ ) and mean potential food abundance $>4500$ nauplii $(N) \mathrm{m}^{-3}$ or $>5500$ of other microzooplankters $(T-N) \mathrm{m}^{-3}$. Apart from the good agreement found between histological and RNA/DNA results, each approach offered different information: histological indices detected the largest portion of unfit larvae at size-ranges $\leq 8 \mathrm{~mm}$, whereas RNA/DNA best discriminated large larvae. The results from this study support the view that links exist between mesoscale anomalies, spawning intensity and growth or condition of pilchard larvae in the NWM.
\end{abstract}

KEY WORDS: Sardina pilchardus · Larvae · Environment · Condition · Growth · Northwestern Mediterranean

\section{INTRODUCTION}

The European pilchard Sardina pilchardus (Walbaum) is one of the most commercially important species in the northwestern Mediterranean (NWM) and supports the largest fishery in terms of biomass on the Catalan coast (Bas 2002), despite a decline in numbers since 1993 (Anonymous 2004). In the NWM, pilchard spawn from October to May over the continental shelf (when temperatures drop below $20^{\circ} \mathrm{C}$ ) reaching maximum spawning activity at temperaures of $<18^{\circ} \mathrm{C}$ (Oliver 1957).

Since Hjort (1914), it has been hypothesized that fluctuations in the recruitment of fishes depend on mortality at the early developmental stages. The main cause of larval mortality is thought to be predation (followed by starvation) on the smaller and/or slowergrowing individuals (Anderson 1988). The recognised difficulty of studying predation in the wild has partly justified the use of indicators of suboptimal feeding or growth as proxies for larval success. The methodological approaches to study growth or nutritionalphysiological status (condition) vary greatly, each offering a set of pros and cons concerning the information they yield, or the costs they involve (Ferron \& Leggett 1994). The relationships between the environment and how larvae grow and survive, and how this 
may be translated into fisheries recruitment, have been the object of numerous papers in fisheries oceanography over the past decades (reviewed in Govoni 2005). However, there is still a vast deficit in information on such relationships, and often the kind of techniques employed greatly limit the interpretation of the results.

Some literature does exists that describes the horizontal and vertical distribution and abundance of pilchard eggs and larvae in the NWM (Olivar et al. 2001, 2003). More recently, Catalán et al. (2004) showed the potential effects of relatively high temperature differences $\left(6^{\circ} \mathrm{C}\right)$ on the growth of field-collected pilchard larvae. Olivar et al. (2003) showed that the horizontal distribution and abundance of pilchard eggs and larvae was related to environmental factors in the 1998 to 1999 spawning season. The authors noted that, at a horizontal scale of tenths of kilometres, abundance was lower in water masses influenced by new Atlantic Waters (AW), characterised by lower surface salinity, slightly increased temperature, and reduced values of fluorescence and potential prey abundance. In that work, however, it was not clarified whether those egg and larval horizontal patterns could be due to differential spawning alone or if larval growth or condition were also affected by the surrounding conditions. The present work tries to answer that question by analysing long-term growth and condition with respect to biotic and abiotic variables in November 1998.

Otolith microstructure has long been used as an indicator of larval age and growth (e.g. Brothers et al. 1976). For pilchard larvae, the daily nature of increments was demonstrated by Ré (1984), and the coincidence between hatching and the first readable ring was shown by Alemany \& Alvarez (1994). It is known that environmental changes can be reflected in the width of otolith rings (Neilson \& Geen 1985) and, therefore, assuming a series of premises, the total otolith width can also be thought of as a measure of long-term growth.

Concerning the condition indices, it has been suggested (e.g. Ferron \& Leggett 1994) that no single condition index is 'the best index', as all offer different information on the physiological status of an individual. There is a need to test different methodologies in samples taken from the same sites (provided the same individual cannot be simultaneously tested for some measurements) in order to compare the information they offer (Govoni 2005).

Histological indices may be the most reliable indicators of condition as different tissues can be graded and reveal large amounts of information about a single individual. Histological data on the response of pilchard larvae to suboptimal food levels under controlled conditions are scarce (Silva \& Miranda 1992).
The general histopathological alterations observed in the absence of food are reasonably maintained across species, which enables the use of literature information to study the tissues of wild-collected specimens (O'Connell 1976, Uriarte \& Balbontín 1987, McFadzen et al. 1997). Within the biochemical condition indices, those based on nucleic acids are the most widely used (see review in Ferron \& Leggett 1994). The amount of DNA in a cell is considered relatively constant, and is often used as a measure of number of cells or larval size. On the other hand, RNA is known to vary greatly both with protein synthesis and during starvation. RNA/DNA ratios have been successfully used to detect growth or condition in several species including European pilchard (Chícharo et al. 1998, Ramírez et al. 2001).

The aim of this work was to study the long-term growth and condition in relation to both biotic and abiotic environmental variables in pilchard larvae collected during the beginning of the 1998 spawning season in the NWM. The results offered by each variable are interpreted from an ecological perspective to relate physiological responses to survival potential.

\section{MATERIALS AND METHODS}

Ichthyoplankton hauls and CTD casts were made at 77 stations in an area of the Catalan coast from 4 to 9 November 1998, onboard the RV 'García del Cid', at the beginning of the pilchard spawning season (Fig. 1).

Two types of Bongo-hauls were taken at each station. Double-oblique hauls ( $60 \mathrm{~cm}$ mouth, $300 \mu \mathrm{m}$ mesh size) equipped with flow-metres (General Oceanics) and depth sensors (Minilog-SPARTEL) were taken

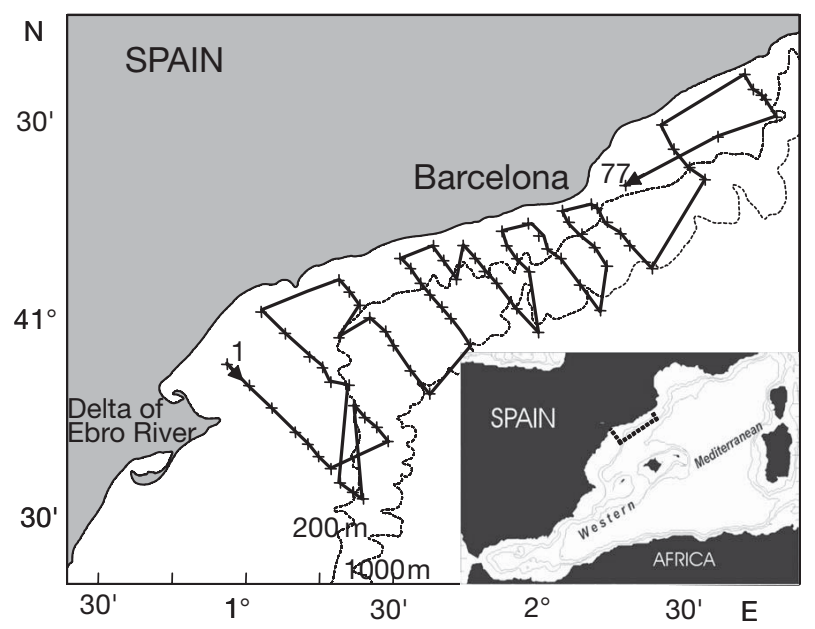

Fig. 1. Location of sampling stations (+) and route followed by the RV 'García del Cid' from Stns 1-77. Dotted lines represent the 200 and $1000 \mathrm{~m}$ isobaths 
(down to $200 \mathrm{~m}$ in depth) in order to describe total abundances (Olivar et al. 2003). For analyses of condition and growth, shorter (ca. $5 \mathrm{~min}$ ) and shallower (maximum depth of $25 \mathrm{~m}$ ) hauls were conducted in order to minimise tissue degradation and sample at a significant depth. According to Olivar et al. (2001), over $50 \%$ of pilchard taken larvae concentrate in the top $20 \mathrm{~m}$. CTD casts were down to $500 \mathrm{~m}$ using a Seabird 25 profiler system. In addition, microzooplankton vertical hauls $(70 \mathrm{~m})$ were made using a $40 \mathrm{~cm}$ mouth Juday-Bogorov net with $53 \mu \mathrm{m}$ mesh size. As soon as the Bongo haul was onboard, the contents of 1 cod-end were poured into a tray and the pilchard larvae sorted into 2 groups. One group was preserved in $10 \%$ phosphate-buffered formalin and later transferred to $70 \%$ ethanol for histological analyses. The second group was deep-frozen individually in liquid nitrogen for biochemical and otolith analyses. The whole sorting process was usually finished between 5 and $10 \mathrm{~min}$ after haul recovery. Depending on larval abundance, between 5 and 15 larvae of a sufficient length-range were preserved from each positive station for each analysis.

Treatment of environmental variables. In order to relate both long-term growth and condition to environmental data, 2 approaches were adopted. Firstly, stations were grouped into 2 widely differing 'environmental groups' (A and B). This was achieved using unrotated principal component analysis (PCA) on the correlation matrix of 7 normalised ( 0 mean and unit standard deviation, SD) environmental variables (see 'Results'). This enabled the comparison of, for example, long-term growth with nutritional condition of larvae collected from stations with similar environmental characteristics. Variables used were depth $(D, \mathrm{~m})$, copepod nauplii $\left(N\right.$, ind $\left.\mathrm{m}^{-3}\right)<45 \mu \mathrm{m}$ in size, other microzooplankton $\left(T-N\right.$, ind $\left.\mathrm{m}^{-3}\right)$, surface temperature at $5 \mathrm{~m}\left(\mathrm{~T} 5,{ }^{\circ} \mathrm{C}\right)$, salinity at $5 \mathrm{~m}(\mathrm{~S} 5)$, integrated fluorescence (F70, 0 to $70 \mathrm{~m}$, volts), and a water stability index (Brunt-Väissälä, B-V, cycles $\mathrm{h}^{-1}$ ), calculated as:

$$
B-V=\sqrt{\frac{g}{\rho} \frac{d \rho}{d z}}
$$

where $g$ is acceleration due to gravity, $\rho$ is water density and $z$ is depth (Mann \& Lazier 1996). The rationale behind the use of this index is that the degree of strength of the pycnocline may interact with the production dynamics, food distribution and larval vertical migration, and therefore might be related to larval nutritional condition. The B-V frequency was calculated for $\mathrm{d} z=2 \mathrm{~m}$ and the maximum value selected for each station. Data on potential food are from Olivar et al. (2003).

In addition, correlation analyses between individual larval condition and the values of each environmental variable associated with the station of collection were performed (using all positive stations and all larvae). This made it possible to explore the importance of individual environmental variables on condition and to assess the suitability of the initial environmental groups selected through PCA. We used the non-parametric Spearman correlations $\left(\mathrm{r}_{\mathrm{s}}\right)$ due to the often nonlinear relationships observed in the plots, even after appropriate data transformation.

Analyses of long-term growth and condition. General: For all the studies, larval length was measured under a binocular microscope to the nearest $0.1 \mathrm{~mm}$. In order to standardise comparisons, all length measurements are given as formalin-preserved standard length (SL, in $\mathrm{mm})$. Frozen individuals were corrected for size using data for $4 \%$ formalin-preserved shrinkage of larval Sardinops melanostictus (Watanabe \& Kuroki 1997). No remains of yolk-sac or oil globule were observed in larvae $>5 \mathrm{~mm}$ (preserved length) in any of the cruises. Larvae under this length were not used for condition analyses as maternal reserves prevent detection of external signals through indices like RNA/DNA (Bergeron 1997). However, all larvae were used for long-term growth analyses as otoliths integrate all the history of the larvae, including yolk-sac stages. Each type of analysis was conducted on a different set of larvae.

Long-term growth: Long-term growth was explored by assessing the relationships between length, estimated age (through otolith ring counts) and otolith diameter. The hypothesis tested was that there were no significant differences in long-term growth between larvae from environmental groups A and B. From each larva, both right and left sagittae were extracted under a dissecting microscope equipped with polarised light. Otoliths were rinsed in distilled water, allowed to dry and mounted with p-xylene-bispyridinium bromide (DPX, SIGMA-ALDRICH) onto slides. The number of daily growth increments and the maximum otolith diameter along the longest otolith axis was determined using an image analyser (OPTIMAS 6.0) connected to a PC through a CCD video camera. When possible, final estimation of age was made by averaging results from both sagittae. Fiftythree larvae from 13 stations were analysed in environmental group A (mean SL $=8.6 \pm 2.57$ [SD]). For environmental group B, 41 larvae from 7 stations were analysed (mean $\mathrm{SL}=7.4 \pm 2.78$ ). According to Alemany \& Alvarez (1994), the number of presumptive daily rings was assumed to indicate age from hatching. The relationship between the examined variables and length was adjusted by either linear, power or exponential functions. Instantaneous growth in otolith diameter $\left(G_{\mathrm{OD}}, \mu \mathrm{m} \mathrm{d} \mathrm{d}^{-1}\right)$ was calculated by taking the derivative of each equation for a given age. Signifi- 


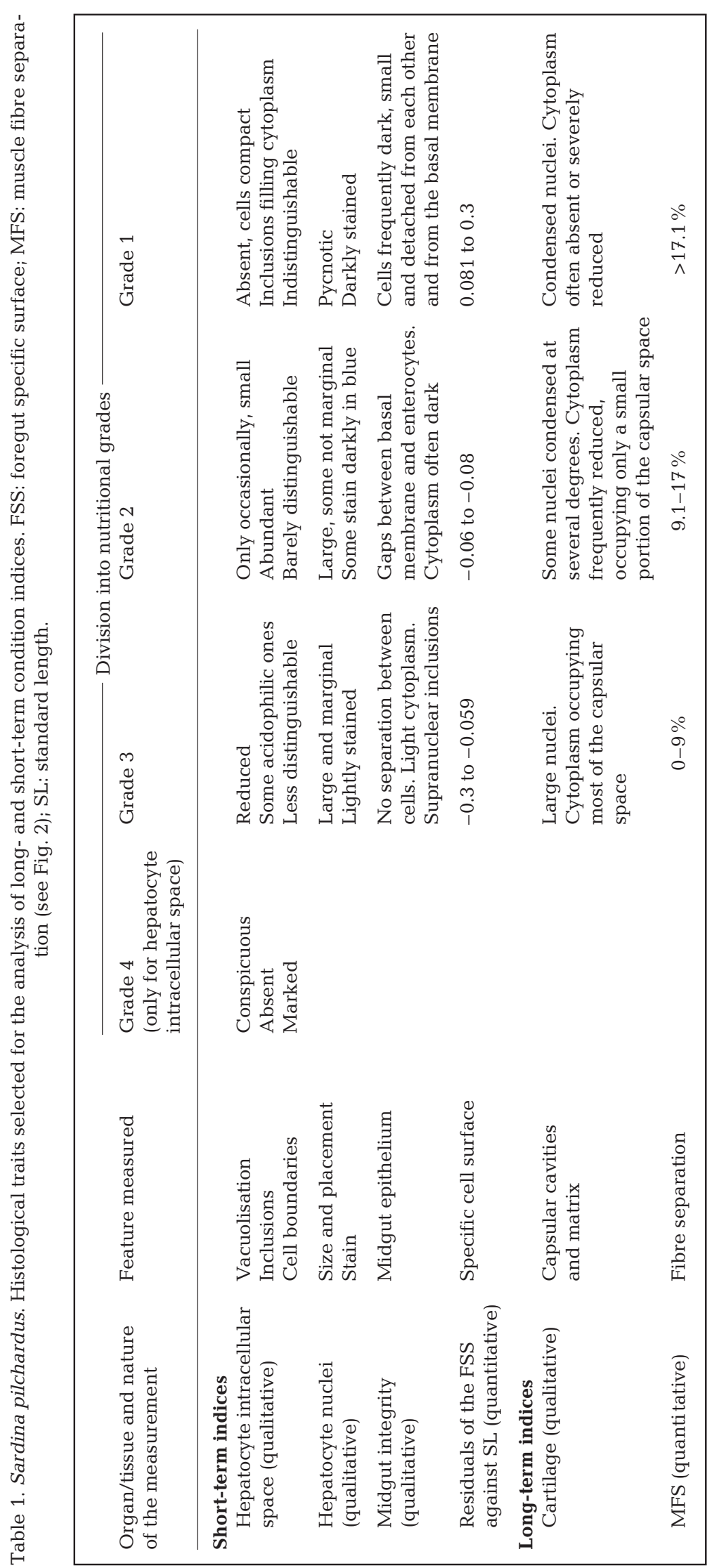

cance of each regression, and differences in slopes and intercepts were tested through general linear model (GLM) techniques on linearised variables (Minitab, v. 12.5). A comparable length-range (3 to $15 \mathrm{~mm}$ SL) was selected from each environmental group.

Condition: A total of 178 larvae were processed for Historesin (Leica) embedding, sectioned at $3 \mu \mathrm{m}$ in an approximate sagittal plane and stained with Lee's methylene blue - basic fuchin (Bennett et al. 1976). Liver, foregut muscle and cartilage were divided into short and longterm response tissues according to the available information in the literature (Table 1): whereas gut and gut-associated glands respond in a time-scale from hours to a few days (Watanabe 1985, Oozeki et al. 1989), the muscle and cartilage are usually degraded when the liver and gut have already responded to suboptimal food regimes (Theilacker 1978, McFadzen et al. 1994). As the latter occurs soon in less developed larvae, we divided the samples into 2 size-classes (8 $\mathrm{mm}$ SL cut point) to account for developmental differences (Table 2).

A large proportion of larvae could not be fully interpreted histologically due to missing guts that were lost during net collection. This explains why the amount of larvae analysed for short-term indices was lower than that for long-term indices (Table 2). Both qualitative and quantitative histological measurements were used (Table 1).

Qualitative histological criteria were derived from the available information on pilchard (Uriarte \& Balbontín 1987, Silva \& Miranda 1992, McFadzen et al. 1997) and on other clupeid larvae (O'Connell 1976, Sieg 1998). Qualitative measurements concerned cartilage and liver. Condition of these tissues was classified into grades according to various cell and tissular characteristics, from 1 (poor condition) to 3 or 4 (good condition) (Table 1).

Quantitative measurements concerned muscle and foregut. Muscle condition was quantified through the degree of muscle fibre separation (MFS), calculated through semi-automated digital image analysis using OPTIMAS 6.0 (Fig. 2a). The MFS is based on the experimental evidence that 
Table 2. Sardina pilchardus. Larvae used for histological analyses, classified by type of index and size-class, for each environmental group. n: number of larvae; SL: standard length; SD: standard deviation

\begin{tabular}{|c|c|c|c|c|c|c|c|c|c|c|c|c|c|}
\hline \multirow[t]{3}{*}{ Group } & \multirow[t]{3}{*}{$\begin{array}{l}\text { No. of } \\
\text { stations }\end{array}$} & \multicolumn{6}{|c|}{$\begin{array}{c}\text { Short-term indices } \\
\text { Larval size-class (SL, in mm) }\end{array}$} & \multicolumn{6}{|c|}{$\begin{array}{l}\text { Long-term indices } \\
\text { Larval size-class (SL, in } \mathrm{mm} \text { ) }\end{array}$} \\
\hline & & & $-\leq 8 \mathrm{~mm}$ & - & & $->8 \mathrm{~mm}$ & - & $\ldots$ & $-\leq 8 \mathrm{~mm}$ & - & & $->8 \mathrm{~mm}-$ & 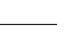 \\
\hline & & $\mathrm{n}$ & Mean SL & $\mathrm{SD}$ & $\mathrm{n}$ & Mean SL & $\mathrm{SD}$ & $\mathrm{n}$ & Mean SL & $\mathrm{SD}$ & $\mathrm{n}$ & Mean SL & SD \\
\hline A & 17 & 32 & 6.8 & 0.90 & 43 & 10.3 & 2.05 & 55 & 6.7 & 0.82 & 77 & 10.2 & 1.88 \\
\hline B & 13 & 10 & 6.0 & 1.30 & 4 & 9.8 & 1.69 & 23 & 6.2 & 1.22 & 23 & 11.7 & 3.06 \\
\hline
\end{tabular}

fish subjected to suboptimal feeding make use of muscle protein as an energy source, which is translated into a loss of fibre cohesion and an increase of inter-fibre gaps (O'Connell 1976, Green \&
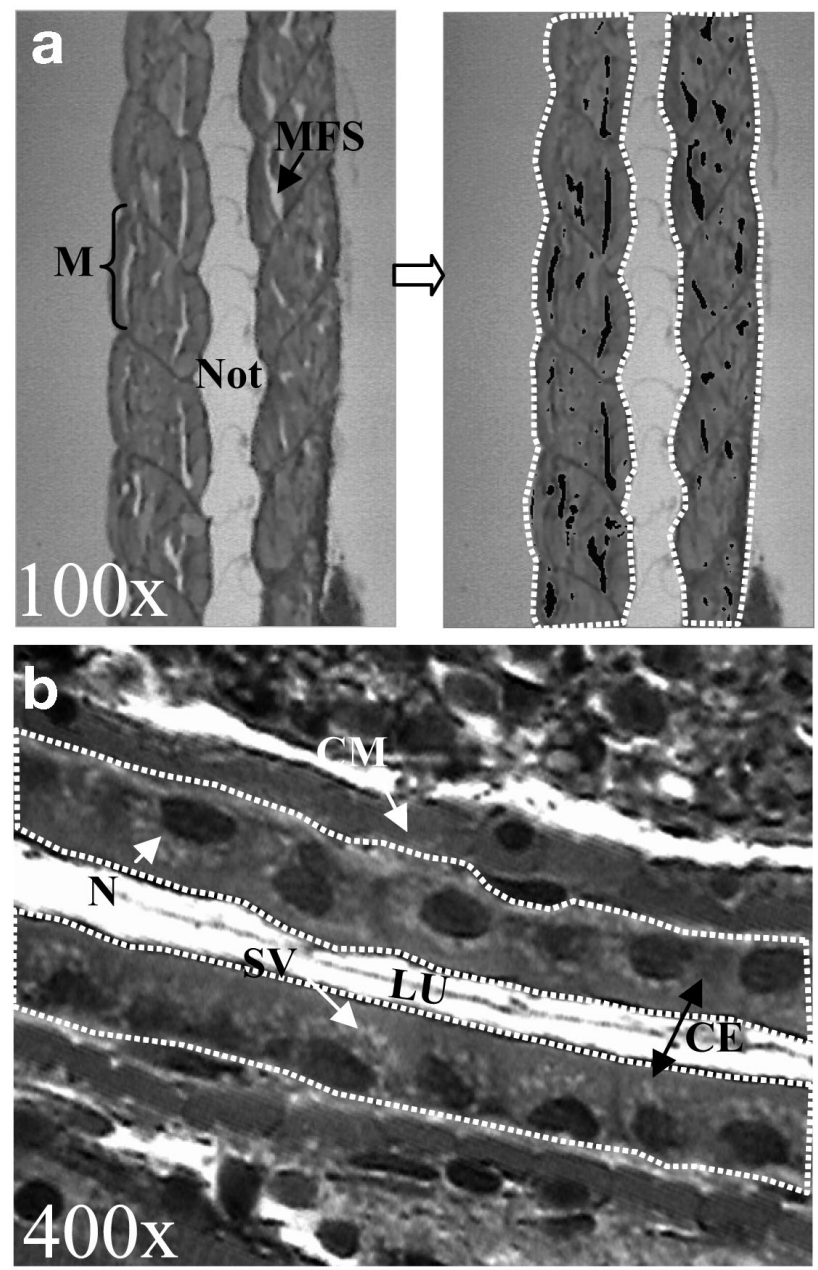

Fig. 2. Sardina pilchardus. Determination of the histological quantitative measurements. (a) Quantification of muscle fibre separation (MFS) (in black, interfibrilar spaces) after semiautomatised digital analysis; (b) foregut specific surface (FSS). The white dotted line denotes the total area selected for measurements. CE: cuboidal epithelium; CM: circular musculature; LU: luminal space; M: myotome; N: nuclei; Not: notochord; SV: supranuclear vacuoles
McCormick 1999). It was chosen over the classical 'subjective' muscle scoring for its best performance in laboratory tests (Catalán \& Olivar 2002). The second quantitative measurement was the ratio between the perimeter of a section of the foregut epithelium and its contained cellular area (foregut specific surface, FSS, Fig. 2b). The higher the ratio, the more the tissue is degraded. This measurement was utilised by (McFadzen et al. 1994) Scophthalmus maximus larvae. Its use was advantageous for our study as it enabled the analysis of specimens at an advanced developmental stage that usually showed a folded midgut. Moreover, the foregut was usually present in specimens that had damaged mid and hindguts. For the classification into grades of the MFS and FSS, for which no literature information was available, we used data of several pilchard larvae kept without food that were hatched onboard during the survey (kept in 51 tanks, gently aerated at ca. $19^{\circ} \mathrm{C}$ ). Although hatching was around $90 \%$, mortality was extremely high and only 2 larvae were recovered on Day 8 after hatching. They showed severe signs of emaciation in several tissues and no yolk was present. According to Miranda et al. (1990), yolk resorption in pilchard larvae kept without food at 18 to $20^{\circ} \mathrm{C}$ would take 5 to $6 \mathrm{~d}$, and death from starvation would occur in 3 to $4 \mathrm{~d}$ after yolk resorption. The values of MFS and FSS surface of these starved larvae were used as reference values indicating poor condition. MFS was 19 and $23 \%$ in these larvae. FSS was 0.41 (only 1 larva was readable). MFS was classified into nutritional classes taking into consideration both the laboratory data and images taken from the literature (Silva \& Miranda 1992, McFadzen et al. 1997). Intervals used are shown in Table 1. FSS was the only variable that significantly correlated with size even within each of the 2 larval size-groups ( $\mathrm{r}_{\text {Pearson }}$ was between -0.41 and -0.29 , $\mathrm{p}$ $<0.001$ in both cases). Therefore, residuals of the FSS against ln SL were used to overcome this problem, which were divided into 3 equal intervals to get the nutritional grading (Table 1).We used the mean values of MFS and cartilage as 'long-term' indices, and the mean values of FSS and liver scores as 'shortterm' histological indices. 
Larvae frozen in liquid nitrogen were transported to the laboratory for nucleic acid analyses. Larval heads and guts were excised prior to the analysis, hence mainly muscle tissue was used. The methods used herein are those described in (Berdalet 2002). Essentially, the method uses the SYBR Green II fluorochrome to estimate DNA and RNA in combination with RNase and DNase digestions, respectively, on separate aliquots. DNA Type I from calf thymus (D-3664, SIGMA) and RNA Type III from baker's yeast (R-7125, SIGMA) were used as standards. The average ratio between all RNA and DNA slopes was 4.0. This can facilitate comparisons of RNA/DNA with future studies (Berdalet et al. 2005). The relationship between SL and RNA/DNA was explored through correlation (Pearson) analysis. As no significant correlation was found, larvae were compared between environmental groups A and B. A total of 76 larvae from 16 stations of group A (mean SL $=8.9 \pm 2.26$ ) and 40 larvae from 7 stations from group B (mean $\mathrm{SL}=8.2 \pm 2.24$ ) were analysed. Between-group comparisons were performed using $t$-tests.

\section{RESULTS}

\section{Environmental variables}

The first 2 PCs explained ca. $74 \%$ of total variance between sampling stations (Table 3, Fig. 3). Most of this variance was explained by opposite trends between potential food ( $N$ and $T-N$ ) and the stratification index (B$\mathrm{V}$ ). We used the first PC ( $52 \%$ of total variance) in order to divide sampling stations into environmental groups 'A' (PC1 scores < 0), formed mainly by stations with low B-V values and high $N$ and $T-N$, and 'B' (PC1 scores $>$ 0 ), defined by high B-V and low $N$ and T-N(Fig. 4). The highest average stratification was concentrated between 20 and $40 \mathrm{~m}$ in environmental group B.

\section{Long-term growth}

The relationship between body length and otolith diameter adjusted well to a power function for both environmental groups (Fig. 5a), indicating that otolith

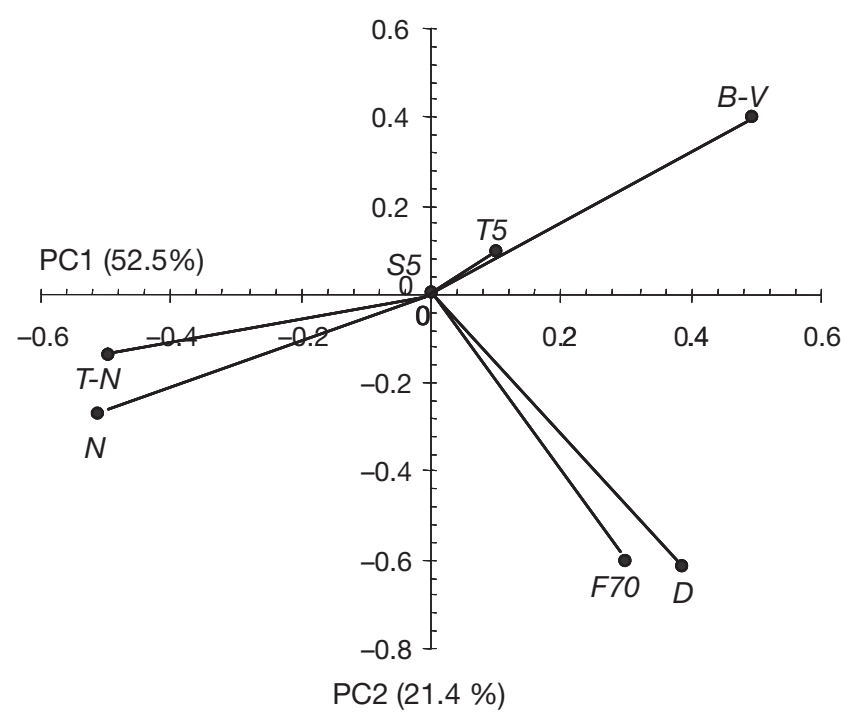

Fig. 3. Loadings and vectors of the first 2 PCs based on 7 environmental variables. Variables as in Table 3

diameter encompassed somatic growth. Although there were no significant differences between slopes in both groups, the mean SL at a given otolith diameter was significantly higher for group A (GLM; $F=4.33$, $\mathrm{p}<0.05)$. For both groups $A$ and $B$, growth in length $\left(G_{\mathrm{L}}\right.$, in $\left.\mathrm{mm} \mathrm{day}^{-1}\right)$ was best described by a linear function (Fig. 5b). $G_{L}$ was 0.77 for group A and 0.63 for group B but there were no significant differences in slopes or intercepts between both areas. The otolith diameter increased with age following an exponential function (Fig. 5c), but no significant differences between the 2 environmental groups were found.

\section{Condition}

Histology

Overall, the nutritional condition of larvae differed between environmental groups A and B. Short-term indices showed a similar pattern between the 2 groups, having the modal class in the intermediate condition. No differences were observed between size-classes (Fig. 6).

Table 3. Results of the PCA performed on the 7 environmental variables. PC: principal component; $D$ : depth; $N$ : nauplii (ind. $\mathrm{m}^{-3}$ ); $T-N$ : other microzooplancters (ind. $\mathrm{m}^{-3}$ ); T5: temperature at $5 \mathrm{~m} ; S 5$ : salinity at $5 \mathrm{~m} ; F 70$ : integrated fluorescence over the first $70 \mathrm{~m}$; B-V: stratification index

\begin{tabular}{|c|c|c|c|c|c|c|c|c|c|}
\hline $\mathrm{PC}$ & $D$ & $N$ & $T-N$ & T5 & S5 & $F 70$ & B-V & Eigenvalue & \% variance \\
\hline 1 & 0.385 & -0.511 & -0.498 & 0.099 & 0.001 & 0.297 & 0.494 & 2.06 & 52.5 \\
\hline 2 & -0.611 & -0.270 & -0.133 & 0.098 & 0.003 & -0.602 & 0.404 & 0.84 & 21.4 \\
\hline 3 & -0.160 & 0.373 & 0.428 & 0.006 & 0.001 & 0.380 & 0.713 & 0.59 & 15.2 \\
\hline
\end{tabular}



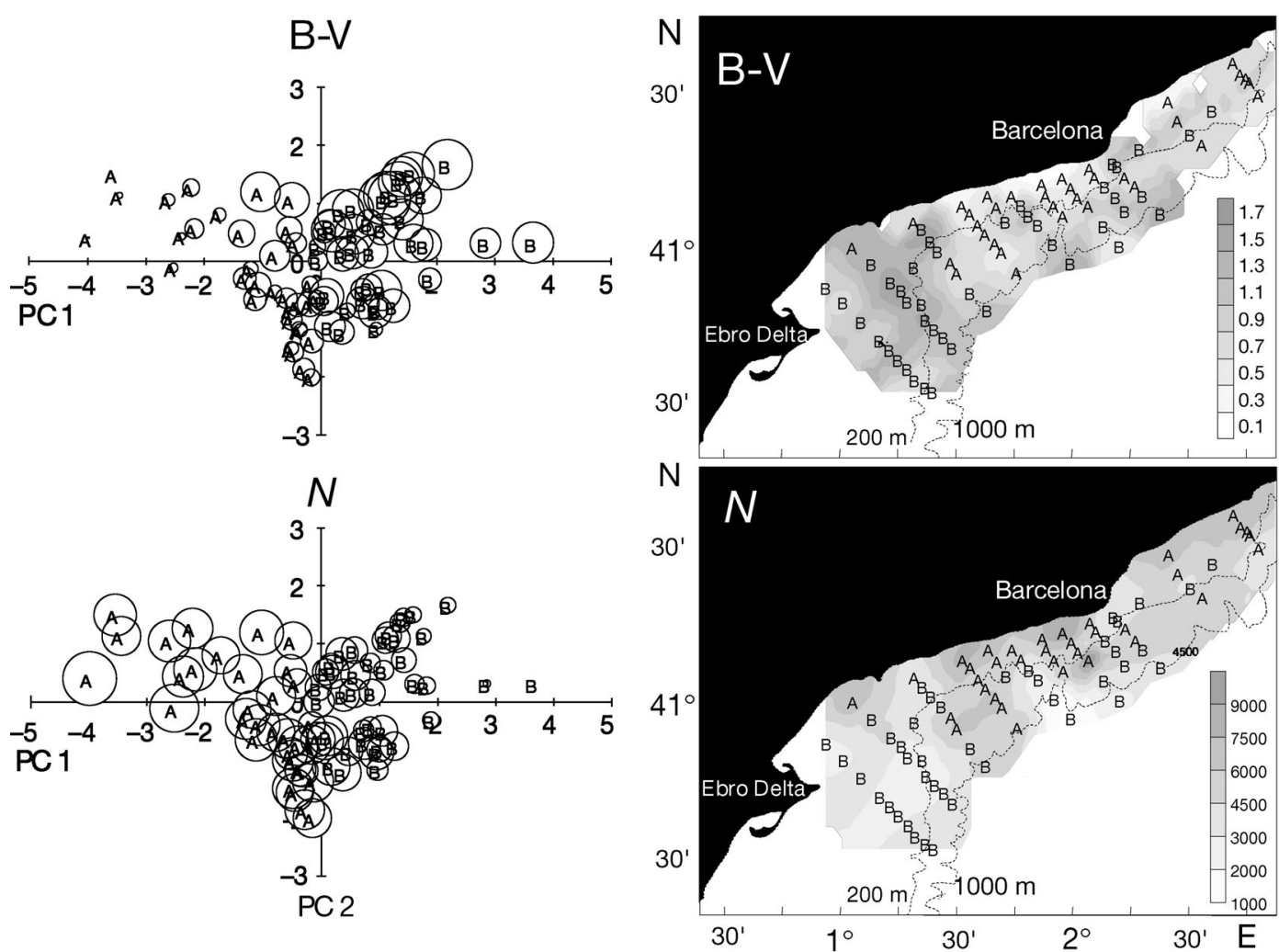

Fig. 4. Definition of environmental groups A and B according to positive or negative values of PC1. Left panels: scores of PCs 1 and 2 with superimposed circles proportional to values of water column stability index (B-V) and nauplii $\mathrm{m}^{-3}(<45 \mu \mathrm{m})(N)$. Right panels: spatial representation of the resulting groups A and B. Nauplii map (bottom right hand panel) is redrawn from Olivar et al. (2003)

On the contrary, the frequency distributions of the longterm index were clearly different between groups A and B. Approximately $80 \%$ of larvae from group A were in good condition, irrespective of size-class. In group B, $80 \%$ of larvae $\leq 8 \mathrm{~mm}$ were either in poor or mid condition. Approximately $75 \%$ of larvae $>8 \mathrm{~mm}$ of group B were in good condition and $24 \%$ showed apparent degradation of muscle and cartilage. Necrotic tissues appeared only in 4 larvae, all from group $B$, of sizes $\leq 8 \mathrm{~mm}$.

Correlations between the 7 environmental variables and short-term indices showed no significant relationships with any of the environmental variables studied, in either the small or larger larvae. The long-term histological condition indices showed significant correlations with all environmental variables but D in the small size larval group, but no significant correlations were found in larvae $>8 \mathrm{~mm}$. From the small larvae, positive correlations were only held with food abundance (for $N_{i} \mathrm{r}_{\mathrm{s}}=0.49, t=4.891, \mathrm{p}<0.0001$; for $T-N_{i} \mathrm{r}_{\mathrm{s}}=$ $0.50, t=5.05, \mathrm{p}<0.001)$. On the other hand, negative correlations were only held with $T 5\left(\mathrm{r}_{\mathrm{s}}=-0.49\right.$, = -4.827, $\mathrm{p}<0.0001)$ and with the B-V $\left(\mathrm{r}_{\mathrm{s}}=-0.44, t=\right.$ $-4.207, \mathrm{p}<0.001)$. Therefore, it was confirmed that the smallest larvae showing higher histological condition indices were found in stations with higher food abundance and lower stratification and temperature.

\section{RNA/DNA}

The mean RNA/DNA values for environmental groups A and B were $7.0 \pm 1.72$, and $6.2 \pm 1.45$, being significantly higher in environmental group A (t-test, $t=2.40, \mathrm{df}=113, \mathrm{p}<0.05$, Fig. $7 \mathrm{~b}$ ).

When all larval sizes and stations were pooled (RNA/DNA was uncorrelated with SL), significant correlations between RNA/DNA and several environmental variables at the site of collection were found. Larvae with higher RNA/DNA values were collected at shallower stations $\left(\mathrm{r}_{\mathrm{s}}=-0.24, \mathrm{n}=116, t=-2.68, \mathrm{p}<0.05\right)$, with a higher abundance of $T-N\left(\mathrm{r}_{\mathrm{s}}=0.31, \mathrm{n}=116, t=\right.$ $3.51, \mathrm{p}<0.0001)$ and lower $F 70$ values $\left(\mathrm{r}_{\mathrm{s}}=-0.34, \mathrm{n}=\right.$ 116, $t=-3.82, \mathrm{p}<0.001)$. Fig. 7a suggests that larger larvae (> ca. $8 \mathrm{~mm}$ ) was the group that differed most between areas A and B. A separate correlation analysis using these larger larvae showed that RNA/DNA correlated with a larger number of environmental variables. Negative correlations were observed with 

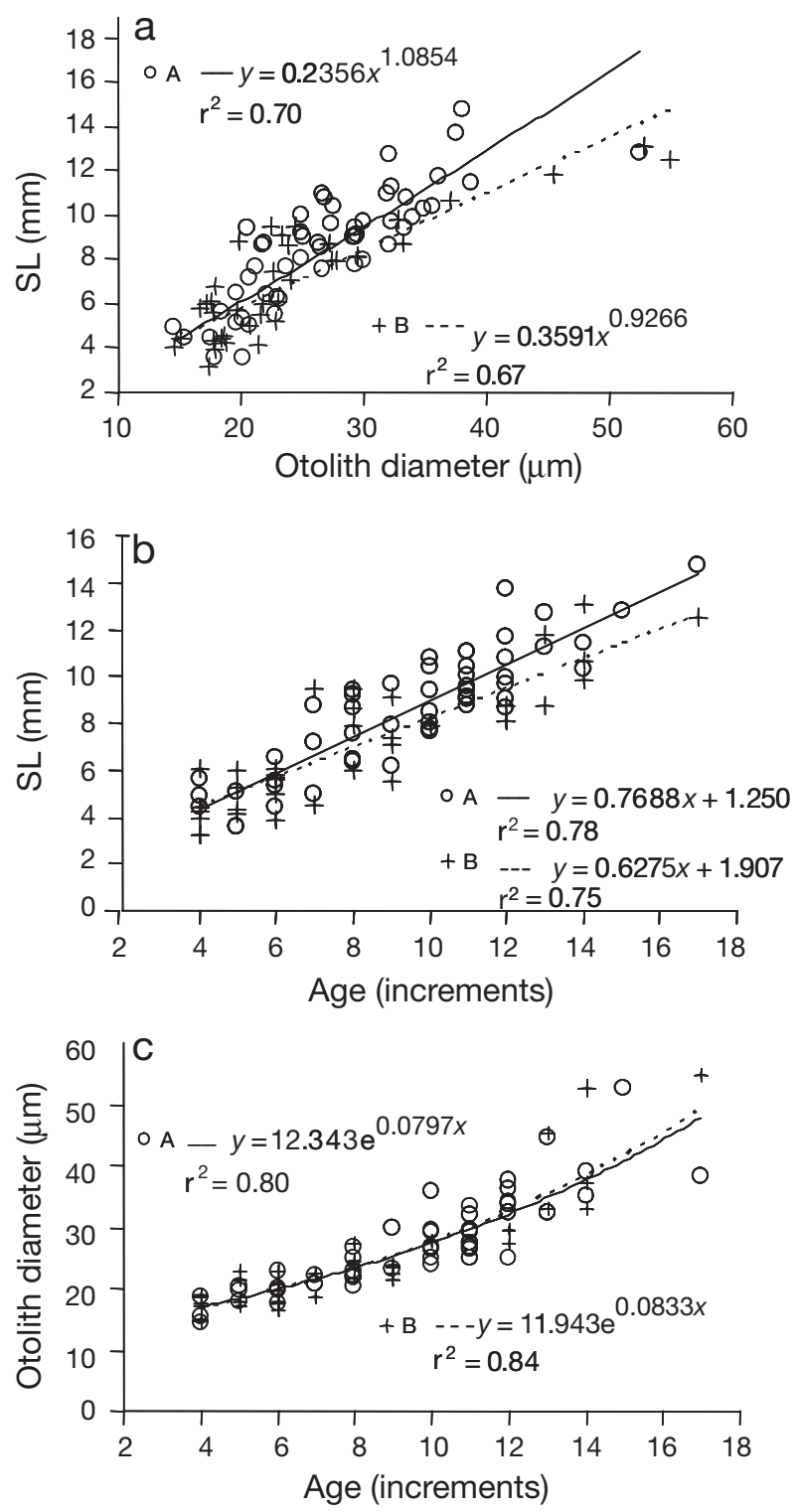

Fig. 5. Sardina pilchardus. For each environmental group, relationships between (a) otolith diameter and $\mathrm{SL}_{\text {; }}$ (b) estimated age and $\mathrm{SL}_{;}$(c) estimated age and otolith diameter. SL: standard length; A, B: environmental groups

respect to the $\mathrm{B}-\mathrm{V}$ index $\left(\mathrm{r}_{\mathrm{s}}=-0.30, \mathrm{n}=71, t=-2.571\right.$, $\mathrm{p}<0.05)$ and $T 5\left(\mathrm{r}_{\mathrm{s}}=-0.28, \mathrm{n}=71, t=-2.363, \mathrm{p}<0.05\right)$ and positive correlations were held with $N\left(\mathrm{r}_{\mathrm{s}}=0.30\right.$, $\mathrm{n}=71, t=2.599, \mathrm{p}<0.05)$. These data agree with the results obtained by histological analyses. On the other hand, when the RNA/DNA of larvae $\leq 8 \mathrm{~mm}$ was confronted with environmental variables, they only correlated significantly and negatively with $D\left(\mathrm{r}_{\mathrm{s}}=-0.27\right.$, $\mathrm{n}=45, t=-2.012, \mathrm{p}<0.05)$. The RNA/DNA values of these smaller larvae, however, showed higher variability than those of larger larvae and were not significantly different between groups A and B (Fig. 7b).

\section{DISCUSSION}

\section{General}

This is the first study that uses several histological indices, RNA/DNA and otolith-derived data to simultaneously approach the relationships between environmental conditions and early growth or condition. Indeed, the existing reviews on condition indices show that the vast majority of field work is based on the use of a single technique (Ferron \& Leggett 1994), with the inherent risk of loosing information on the different eco-physiological processes that may condition survival.

The observed surface temperature range in the present work (ca. 18 to $20^{\circ} \mathrm{C}$ ) was 2 to $4^{\circ} \mathrm{C}$ higher than the norm, and more stratified than the usual values for that time of the year (Salat et al. 2002). The differences in horizontal and vertical hydrographic structure encountered, which basically defined the environmental groups A and B, were interpreted in Olivar et al. (2003) as a result of the intrusion of new AW (less saline and warmer (more buoyant) water) detected in the area by Pascual et al. (2002). Environmental groups A and B broadly coincide with zones of maximum (A) or minimum (B) egg and larval abundances as cited in Olivar et al. (2003). Therefore, better condition associated with higher abundances of eggs and larvae suggests that the environmental factors affected both the spawners and the potential survival of the offspring.

The goodness of 'habitat' definition using PC1 was partly supported by the aforementioned differences in larval abundance, and by the significant correlations between condition (histological and biochemical) and the main explanatory variables in PC1. In general, correlations with other variables were either non-significant or lower than the aforementioned ones. Other PCA settings yielded similar between-group results, although the limited number of larvae for the 3 indices prevented a proper analysis of sensibility. The assumption that pilchard larvae distribution is stationary at the early stages, within the environmental groups during the sampling period, was partly supported by the low wind speed registered during the cruise (mean speed $<4 \mathrm{~m} \mathrm{~s}^{-1}$ ). The observation of sea surface temperature (SST) from AVHRR (Advanced Very High Resolution Radiometer) (1.1 km res., NOAA) for the week before collection revealed slightly higher mean surface temperature, (ca. $0.5^{\circ} \mathrm{C}$ ) in the whole area, suggesting that no strong vertical mixing was taking place, and depicting a relatively stable situation at the surface. In addition, the influence of the new AW (present from October 1998 to February 1999, Pascual et al. 2002) disrupted the quasi-permanent southwestern shelfbreak current, and probably contributed by enhancing 


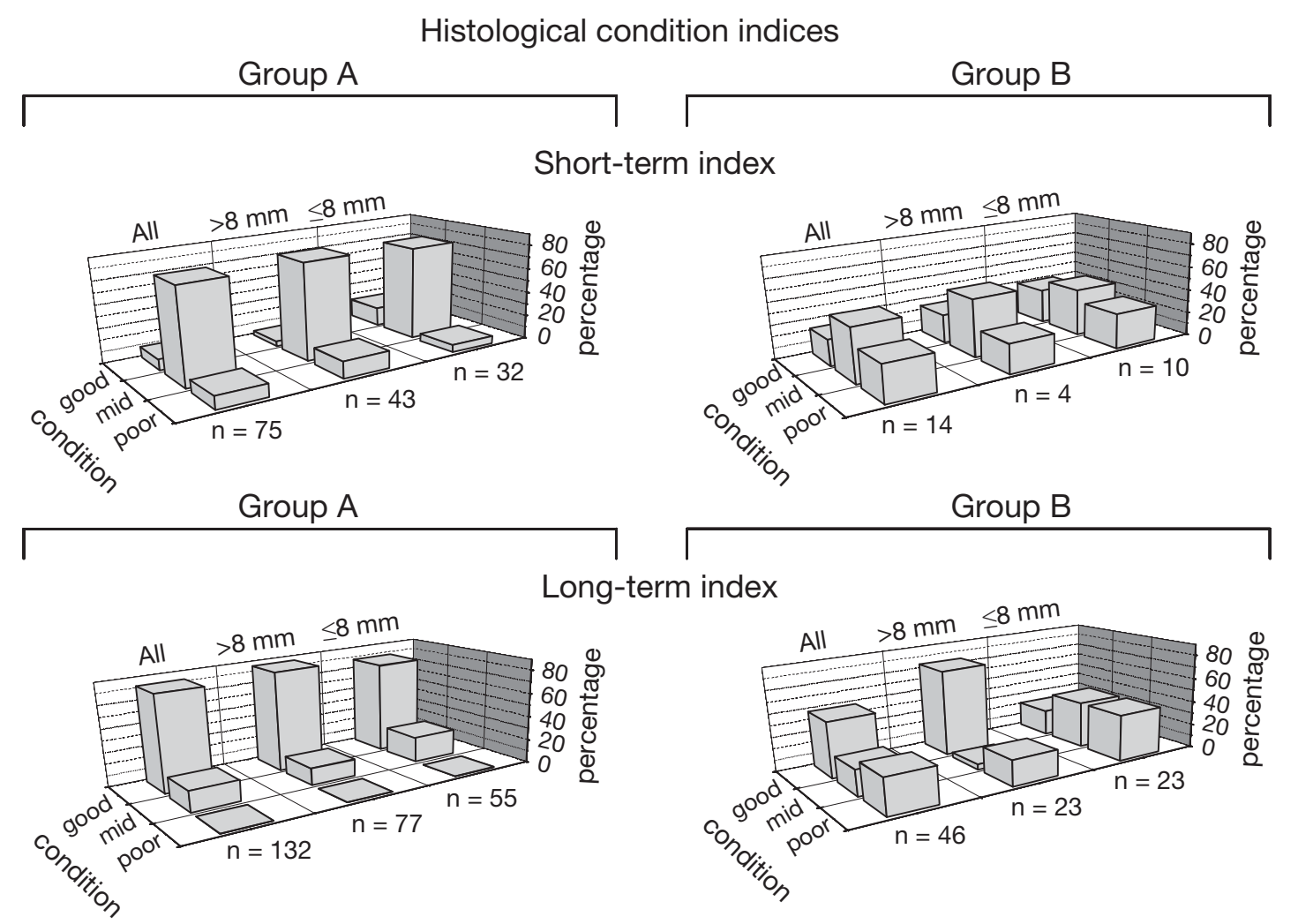

Fig. 6. Sardina pilchardus. Frequency distributions of histological indices for each environmental group and size-class. Short-term indices are based on liver scores and FSS surface. Long-term indices are based on MFS and cartilage (see Table 1)
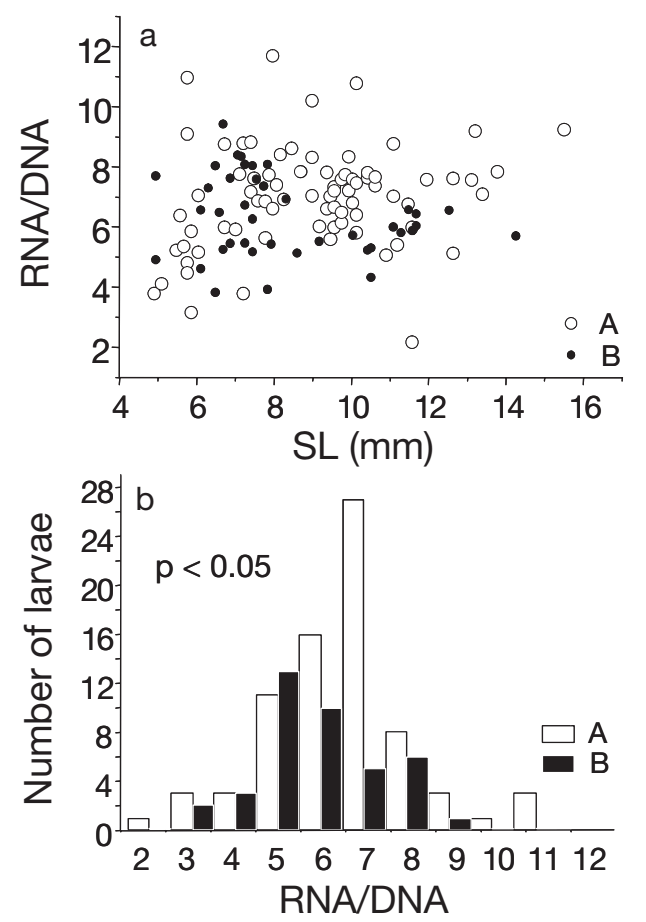

Fig. 7. Sardina pilchardus. (a) RNA/DNA values vs. SL; (b) frequency distribution for RNA/DNA in the 2 environmental groups. SL: standard length; A, B: environmental groups. $\mathrm{p}$ value obtained after $t$-test is shown in (b) the stability in the study area. Further, Olivar et al. (2003) showed that the larval size frequency distribution at the central area (broadly corresponding to our environmental group A included a higher proportion of large size-classes, suggesting a putative retention mechanism in the area. Whereas environmental changes in the $2 \mathrm{wk}$ prior to the survey might have affected the otolith-based analyses, it is considered that histological and RNA/ DNA changes may not be affected by past changes over a few days.

\section{Abundance and adequacy of potential food}

The presented data on potential food (from Olivar et al. 2003) are known to be representative of the diet of pilchard larvae, which first feed on copepod nauplii and gradually incorporate most copepodite stages as they grow (Conway et al. 1994). According to the authors, nauplii may be an important food source for larvae $<8$ to $10 \mathrm{~mm}$, whereas the copepodites would have a bigger influence on the larger larvae. In the present cruise, the median of nauplii abundance was ca. 4400 nauplii $\mathrm{m}^{-3}$, and variability was high between stations (1500 to 9500 nauplii $\mathrm{m}^{-3}$ ). The values for $T-N$ were approximately $20 \%$ higher than for $N$ and they both showed 


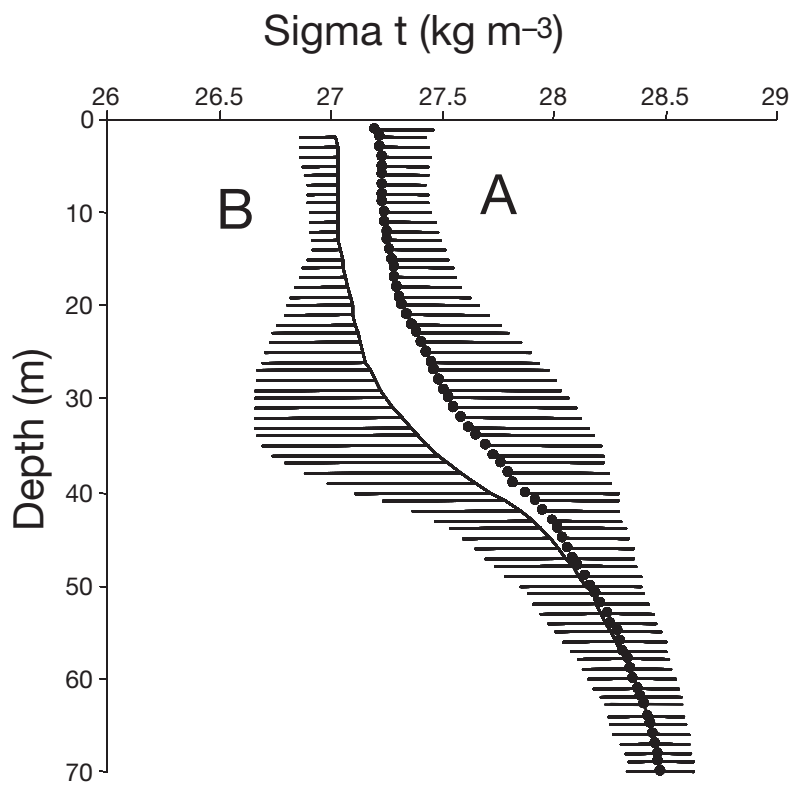

Fig. 8. Mean vertical sigma $\mathrm{t}\left(\mathrm{kg} \mathrm{m}^{-3}\right)$ profiles down to $70 \mathrm{~m}$ for the stations of environmental groups A and B. Horizontal bars (only half is shown for clarity) are 1.96 SD

similar variability values. These median values are generally lower than those found by other authors in the NWM (e.g. Sabatés et al. 2001). On the other hand, this wide among-station variability, suggests that condition and growth may vary at least at the scale of horizontal zooplankton patchiness. Indeed, several studies showed correlations between food abundance at sampling stations and nutritional condition in pilchard larvae (e.g. Chícharo et al. 1998). However, it cannot be ignored that food availability might have been higher than expected from our values on abundance, due to patchiness of prey and larvae at the vertical scale, active larval vertical migration or turbulence through different mechanisms (Franks 2001). In the present work, the generally higher abundance of potential prey in environmental group A could have several causes. Enhanced vertical mixing probably occurred at these stations (Fig. 8). This might lead to higher nutrient availability at surface enhancing production (Olivar et al. 2003). Information on larval vertical distribution patterns (Olivar et al. 2001) showed that pilchard larvae tend to concentrate at the top $20 \mathrm{~m}$ during the day and are more disperse at night. Higher zooplankton at the depth where pilchard may be feeding during the day could account for the observed better condition of the larvae, although this cannot be solved without depthspecific microzooplankton data. On the other hand, the presence of new AW water in the area, particularly affecting stations B, might not only discourage the growth of local zooplankton populations but also negatively affect the zooplanktonic species-specific composition.

\section{Long-term growth}

The only significant difference between the environmental groups in terms of long-term growth was found between body length and otolith diameter. Slopes did not differ between groups $A$ and $B$, but mean otolith diameter was larger in larvae from group B, the a priori most unfavorable environment. Higher mean temperature in group B may explain the fact that smaller larvae showed larger otoliths. Indeed, some authors have observed that otolith growth is highly dependent on temperature, whereas body growth may respond more directly to a combination of temperature, food abundance, changes in development etc. (e.g. Fey 2001).

The observed length-at-age relationships was comparable to that reported for the same species in other areas. During the cruise, mean $T 5$ was ca. $19^{\circ} \mathrm{C}$, and the pooled $G_{\mathrm{L}}$ value was $0.64 \mathrm{~mm} \mathrm{~d}^{-1}(0.77$ in zone $\mathrm{A}$, 0.63 in zone $\mathrm{B}$, mean $\mathrm{T} 5$ being ca. $1^{\circ} \mathrm{C}$ higher in zone B). In SWM pilchard from the Alboran Sea, Ramírez et al. (2001) showed a $\mathrm{G}_{\mathrm{L}}=0.43 \mathrm{~mm} \mathrm{~d}^{-1}$ for Day 15 (mean surface temperature $=15^{\circ} \mathrm{C}$ ). For North Atlantic pilchard, Ré (1984) showed mean growth values of $0.49 \mathrm{~mm} \mathrm{~d}^{-1}$ for temperatures of $15.6^{\circ} \mathrm{C}$. The generally higher growth rates observed in our cruise could be explained by differences in mean temperature and in the length-range considered. The aforementioned authors analysed larvae ranging from 11.4 to $29 \mathrm{~mm}$ (Ramírez et al. 2001) and from 8 to 26 mm (Ré 1984), whereas the largest specimen in the present study was $15.5 \mathrm{~mm}$ SL.

Despite the significant differences observed in SL otolith diameter, the lack of between-group significant differences in age-length data is not surprising. The final otolith diameter of a given collected specimen is the result of the addition of daily rings that may be of different thickness depending on past environmental conditions. Although the relationship between daily increments and length at the time of capture has been successfully used to estimate larval growth (Brothers et al. 1976, Palomera et al. 1988), this technique only enables a gross view of the growth parameters from the sampled population.

\section{Condition}

Histology

At present, histological criteria have not been successfully calibrated with regard to organ reaction of starving European pilchard larvae. In this respect, the existing laboratory data of this species (Silva \& Miranda 1992) are difficult to interpret due to the high mortality observed in their control group (fed larvae). The inter- 
pretation of tissue and cell variability in this study can be considered robust as responses in a variety of species (clupeid and non-clupeid) are similar (Theilacker 1978, Oozeki et al. 1989, Catalán \& Olivar 2002).

Although increased tissue complexity was not observed throughout the size range analysed, organ growth during larval development is known to affect the sequence of energy usage as well as the duration of a particular energy reserve (Ferron \& Leggett 1994). Therefore, the division into developmental stages, or at least size classes, as done in the present work, is justified. According to various works on the European pilchard larvae (Blaxter 1969, Miranda et al. 1990, Silva \& Miranda 1992), complete yolk-sac resorption occurs between 6 and $7 \mathrm{~d}$ old at temperatures of between 13 and $18^{\circ} \mathrm{C}$, with corresponding size ranges from 4.5 to $5.5 \mathrm{~mm}$ ( $4 \%$ formalin-preserved SL). Therefore, our $8 \mathrm{~mm}$ SL cut off point for separating 'small' from 'large' larvae clearly separates individuals that are developing digestive and feeding abilities from larvae with well-established external feeding.

We believe that sufficient evidence was provided to establish a relationship between the environment and condition according to long-term histological indices. However, this was not reflected by the short-term condition index. The intermediate state of the short-term index for both sizes might indicate that larvae had not been subjected to severe starvation prior to collection. It is known that short-term indices, and particularly liver and gut, can respond to food intake from periods of hours to a few days (Watanabe 1985, Oozeki et al. 1989). Differences between the environmental groups were conspicuously shown by the long-term index of condition and were evident in larvae of $\leq 8 \mathrm{~mm}$ (Fig. 6), which is in accordance with the lower resistance to starvation of the less developed larvae. Our microscope observations showed that the muscle index (MFS) was mostly responsible for the differences in condition between the environmental groups, whereas cartilage only responded in cases of severe degeneration of muscle tissue. The fact that muscle tissue responds better and faster than cartilage to lowered food concentration is well documented in the literature. Fish are known to mobilise muscle protein during suboptimal feeding in order to supply maintenance energy (Love 1970, Pedersen et al. 1990). In the youngest stages, energy reserves in the form of lipids or glycogen are minimal, and muscle degradation will be almost immediate in the absence of the required external energy input (O'Connell 1976, Green \& McCormick 1999, Catalán \& Olivar 2002). On the contrary, cartilage is known to respond only to prolonged periods of food deprivation (Theilacker 1978, McFadzen et al. 1994). Therefore, for group $B$, the better condition of larvae $>8 \mathrm{~mm}$ with respect to those $\leq 8 \mathrm{~mm}$ could be explained by an in- creased buffer capacity due to larger storage reserves. In view of the aforementioned sensitivity of gut and liver to food ingestion at the earliest developmental stages the lowered condition of the smaller larvae according to the long-term index does not contradict the intermediate gradation shown by the short-term index. There was good agreement in the correlation analysis of long-term condition vs. environmental variables, and the divisions into groups $\mathrm{A}$ and $\mathrm{B}$ as potentially influencing condition. Relationships between a poorer histological condition and lowered food concentration in field-collected clupeoid larvae has been previously reported (Sieg 1998), although data showing no relationships are also available (O'Connell 1980, McFadzen et al. 1997). Evidence of improved condition with development, as found in this study, is abundant and has been found for both wild and reared larvae (O'Connell 1980, Theilacker \& Porter 1995). The latter has been explained in terms of an increased amount of body reserves, but other factors could also play a role, like the increased potential prey size and species range (Conway et al. 1994, Tudela et al. 2002). The geographically closest study on pilchard condition assessed through histology was conducted by McFadzen et al. (1997) in the Atlantic Iberian waters. They found that the vast majority of the larvae analysed were in good condition as assessed by short-term and long-term indices. They reported, however, a high percentage of starving larvae (up to $30 \%$ ) identified by necrotic tissues. Our results showed far lower values $(2.2 \%)$. However, the mean length of larvae examined by McFadzen et al. (1997) was consistently lower than ours, which could explain their higher proportion of necrotic larvae (higher mortality is observed in smaller individuals). The mean nauplii concentration in our cruises was of the same order as theirs. Our results are more in accordance with those of F. Balbontin (unpubl.), who found values of ca. of 11 to $13 \%$ of necrotic Sardinops sagax larvae, calculated from histological grading. However, the large proportion of larvae in suboptimal condition detected in area B (80\%) indicates that susceptibility to total mortality might be higher.

\section{RNA/DNA}

Due to methodological questions related to the use of fluorochromes for the estimation of RNA and DNA, our absolute RNA/DNA values cannot be directly compared with the literature (Berdalet et al. 2005). The significant differences found between environmental groups (Fig. 7b) agreed with the histological analyses and with the idea that habitat traits were better for larval development in group A than in B. The correlation analyses also supported this view, and showed that the 
amount of potential food was an important variable explaining condition. It was evident from Fig. 7 a that larvae $>8 \mathrm{~mm}$ differed most between groups $\mathrm{A}$ and $\mathrm{B}$. The unsuitability of RNA/DNA for detecting starvation during transition to exogenous feeding has been repeatedly demonstrated and pointed out as drawback for the use of RNA/DNA at the earliest developmental stages (Clemmesen 1996, Bergeron 1997). The fact that none of our analysed larvae showed signs of yolk, plus the fact that we used mainly only 1 type of tissue for the analyses (muscle), reduced the possibility of ontogenetic artifacts in the interpretations of RNA/ DNA as a condition measurement. RNA/DNA ratios have proved sensitive to food availability in many studies on larval fish species including European pilchard (Chícharo et al. 1998). These authors found that between 17 and $20 \%$ of their RNA/DNA variability was explained by zooplankton biomass, values that are comparable to the results obtained herein through correlation analyses.

A factor also influencing RNA/DNA is temperature. Some authors have shown an increased RNA/DNA ratio in relatively colder temperatures, as a probable thermoaclimatory compensation for lowered RNA activity in colder waters (Goolish et al. 1984). Further, several works have proposed models that adequately link RNA/DNA ratios and growth rates correcting for temperature differences higher than $2^{\circ} \mathrm{C}_{i}$ otherwise direct comparison of RNA/DNA values can be done (Buckley 1984). Apart from differences attributed to the studied species, it does not seem likely that temperature difference was responsible for the observed differences in the mean RNA/DNA values in our field study, where the mean surface temperature showed only ca. $1^{\circ} \mathrm{C}$ between-group difference.

Summarising, certain areas at the beginning of the spawning season of pilchard could be environmentally characterised, in which condition, as assessed by histological methods and RNA/DNA, was particularly high. These areas may be described by ranges of environmental values that form a favorable frame for potential larval success. Such a suite of favorable conditions could be broadly defined by $T 5$ values $<19^{\circ} \mathrm{C}$, B-V values $<0.8$ cycles $\mathrm{h}^{-1}$ and mean $N$ or $T-N>4500$ ind. $\mathrm{m}^{-3}$ or $>5500$ ind. $\mathrm{m}^{-3}$, respectively. The areas characterising the unfavorable environment, where condition was lower, would exhibit $T 5$ values $>19^{\circ} \mathrm{C}$, values of $\mathrm{B}-\mathrm{V}$ ranging 0.81 to 1.7 cycles $\mathrm{h}^{-1}$ and potential food abundance below the aforementioned values. As shown in Pascual et al. (2002), these areas were probably influenced by the presence of a mesoscale eddy of new AW. These fresher and warmer waters disrupted the southwestern flow of the shelf-break current and defined a higher-than usual average temperature and stratification (Salat et al. 2002, Olivar et al. 2003). The present results all point towards a reduced growth in environ- mental zone $\mathrm{B}$, where the unusual conditions were more evident. The information offered by the methods tested must be interpreted at different time-scales. Long-term growth, which incorporated all the past history of the larvae, only suggested that individuals at environmental group A might be growing at higher rates, whereas significantly better condition (reflecting relatively recent physiological history) was found in that station group, according to both histological and RNA/DNA values. This cumulative evidence, added to the higher abundances of eggs and larvae found by Olivar et al. (2003) in areas broadly coinciding with group A, establish a link between mesoscale oceanographic processes, spawning intensity and potential survival of pilchard larvae in the NWM.

Acknowledgements. The authors are grateful to M. Emelianov for his assistance with the processing of oceanographic data and to C. Roldán and B. Aguilera for their help in laboratory analyses. Our gratitude also goes to all participants in the cruise. We thank the 3 anonymous referees for their helpful comments on the early version of the manuscript. This research was complied in accordance with all the Spanish laws and was funded by the Spanish research project CYTMAR 97-0902. During this work, I.A.C. was financially supported by a FPI fellowship from the MCYT of the Spanish Government.

\section{LITERATURE CITED}

Alemany F, Alvarez F (1994) Formation of initial daily increments in sagittal otoliths of reared and wild Sardina pilchardus yolk-sac larvae. Mar Biol 121:35-39

Anderson JT (1988) A review of size dependent survival during pre-recruit stages of fishes in relation to recruitment. J North Atl Fish Sci 8:55-66

Anonymous (2004) Sixth Report of the SubCommittee of Stock Assessment (SCSA). General Fisheries Commission for the Mediterranean, GFCM-FAO.

Bas C (2002) El mar Mediterráneo: Recursos vivos y explotación. Ariel Ciencia, Barcelona, p 1-518

Bennett HS, Wyrick AD, Lee SW, McNeil JW (1976) Science and art in preparing tissues embedded in plastic for light microscopy, with specific reference to glycol metacrylate, glass knives and simple stains. Stain Technol 51:71-97

Berdalet E (2002) Quantization of nucleic acids in marine microplankton samples. In: Subba Rao DV (ed) Pelagic Ecology Methodology. AA Balkema, Lisse, p 271-289

Berdalet E, Róldán C, Olivar MP (2005) Quantifying RNA and DNA in planktonic organisms with SYBR Green II and nucleases. Part B. Quantification in natural samples. Sci Mar 69(1):17-30

Bergeron JP (1997) Nucleic acids in ichthyoplankton ecology: a review, with emphasis on recent advances for new perspectives. J Fish Biol 51:284-302

Blaxter JHS (1969) Experimental rearing of pilchard larvae, Sardina pilchardus. J Mar Biol Assoc UK 49:557-575

Brothers EB, Mathews CP, Lasker R (1976) Daily growth increments in otoliths from larval and adult fishes. Fish Bull 74:1-8

Buckley LJ (1984) RNA-DNA ratio: an index of larval fish growth in the sea. Mar Biol 80:291-298 
Catalán IA, Olivar MP (2002) Quantification of muscle condition using digital image analysis in Dicentrarchus labrax larvae, and relationship with survival. J Mar Biol Assoc UK 82:1-6

Catalán IA, Johnston IA, Olivar MP (2004) Seasonal differences in muscle fibre recruitment of pilchard larvae in the Northwestern Mediterranean. J Fish Biol 64:1605-1615

Chícharo MA, Chícharo L, Valdés L, López-Jamar E, Ré P (1998) Estimation of starvation and diel variation of the RNA/DNA ratios in field-caught Sardina pilchardus larvae off the north of Spain. Mar Ecol Prog Ser 164:273-283

Clemmesen CM (1996) Importance and limits of RNA/DNA ratios as a measure of nutritional condition in fish larvae. In: Watanabe Y, Yamashita Y, Oozeki Y (eds) Survival strategies in early life stages of marine resources. AA Balkema, Rotterdam, p 67-82

Conway DVP, Coombs S, Fernández de Puelles ML, Tranter PRG (1994) Feeding of larval sardine, Sardina pilchardus (Walbaum), off the north coast of Spain. Bol Inst Esp Oceanogr 10:165-175

Ferron A, Leggett WC (1994) An appraisal of condition measures for marine fish larvae. Adv Mar Biol 30:217-303

Fey DP (2001) Differences in temperature conditions and somatic growth rate of larval and early juvenile springspawned herring from the Vistula Lagoon, Baltic Sea manifested in the otolith to fish size relationship. J Fish Biol 58: $1257-1273$

Franks PJS (2001) Turbulence avoidance: An alternate explanation of turbulence-enhanced ingestion rates in the field. Limnol Oceanogr 46:959-963

Goolish EM, Barron MG, Adelman IR (1984) Thermoacclimatory response of nucleic acid and protein content of carp mussel tissue: influence of growth rate and relationship to glycine uptake by scales. Can J Zool 62:2164-2170

Govoni JJ (2005) Fisheries oceanography and the ecology of early life histories of fishes. Sci Mar 69 (Suppl 1): 125-137

Green BS, McCormick MI (1999) Influence of larval feeding history on the body condition of Amphiprion melanopus. J Fish Biol 55:1273-1289

Hjort J (1914) Fluctuations in the great fisheries of Northern Europe. Rapp P-V Reun Cons Int Explor Mer 20:1-228

Love RM (1970) The chemical biology of fishes, Vol 1. Academic Press, New York

Mann K, Lazier J (1996) Dynamics of marine ecosystems. Biological-physical interactions in the ocean. Blackwell Science, Boston, MA, p 1-394

McFadzen IRB, Lowe DM, Coombs SH (1994) Histological changes in starved turbot larvae (Scophthalmus maximus) quantified by digital image analysis. J Fish Biol 44: 255-262

McFadzen IRB, Coombs SH, Halliday NC (1997) Histological indices of the nutritional condition of sardine, Sardina pilchardus (Walbaum) larvae off the north coast of Spain. J Exp Mar Biol Ecol 212:239-258

Miranda A, Cal RM, Iglesias J (1990) Effect of temperature on the development of eggs and larvae of sardine Sardina pilchardus Walbaum in captivity. J Exp Mar Biol Ecol 140: 69-77

Neilson JD, Geen GH (1985) Effects of feeding regimes and diel temperature cycles on otolith increment formation in juvenile chinook salmon, Oncorhynchus tshawytscha. Fish Bull 83:91-101

O'Connell CP (1976) Histological criteria for diagnosing the starving condition in early post yolk sac larvae of the northern anchovy, Engraulis mordax Girard. J Exp Mar Biol Ecol 25:285-312

Editorial responsibility: Howard I. Browman (Associate Editor-in-Chief), Storebø, Norway
O'Connell CP (1980) Percentage of starving northern anchovy Engraulis mordax larvae in the sea as estimated by histological methods. Fish Bull 78:475-489

Olivar MP, Salat J, Palomera I (2001) Comparative study of spatial distribution patterns of the early stages of anchovy and pilchard in the NW Mediterranean Sea. Mar Ecol Prog Ser 217:111-120

Olivar MP, Catalán IA, Emelianov M, Fernández de Puelles ML (2003) Early stages of Sardina pilchardus and environmental anomalies in the Northwestern Mediterranean. Estuar Coast Shelf Sci 56:609-619

Oliver M (1957) Biology of the sardine of the Balearic Islands. Cons Gen Pech Med, Deb Doc Tech 4:51-62

Oozeki Y, Ishii T, Hirano R (1989) Histological study of the effects of starvation on reared and wild-caught larval stone flounder, Kareius bicoloratus. Mar Biol 100:269-275

Palomera I, Morales-Nin B, Lleonart J (1988) Larval growth of anchovy, Engraulis encrasicolus, in the Western Mediterranean Sea. Mar Biol 99:283-291

Pascual A, Nardelli B, Larnicol G, Emelianov M, Gomis D (2002) A case of an intense anticyclonic eddy in the Balearic Sea (Western Mediterranean). J Geophys Res 107:1-14

Pedersen BH, Ugelstad I, Hjelmeland K (1990) Effects of a transitory, low food supply in the early life of larval herring (Clupea harengus ) on mortality, growth and digestive capacity. Mar Biol 107:61-66

Ramírez T, Cortes D, García A (2001) Growth of North Alboran Sea sardine larvae estimated by otolith microstructure, nucleic acids and protein content. J Fish Biol 59: 403-415

Ré P (1984) Evidence of daily and hourly growth in pilchard larvae based on otolith growth increments, Sardina pilchardus (Walbaum, 1792). Cybium 8:33-38

Sabatés A, Salat J, Olivar MP (2001) Advection of continental water as an export mechanism for anchovy, Engraulis encrasicolus, larvae. Sci Mar 65:77-87

Salat J, García M, Cruzado A, Palanques A and 7 others (2002) Seasonal changes of water mass structure and shelf slope exchanges at the Ebro shelf (NW Mediterranean). Cont Shelf Res 22:327-346

Sieg A (1998) A study on the histological classification of the in situ-nutritional condition of larval South-west Atlantic anchovy, Engraulis anchoitia Hubbs and Marini, 1935. Arch Fish Mar Res 46:19-35

Silva A, Miranda A (1992) Laboratory rearing of sardine larvae, Sardina pilchardus (Walb.), and early effects of starvation: a preliminary experiment. Bol Inst Esp Oceanogr 8: 163-174

Theilacker GH (1978) Effect of starvation on the histological and morphological characteristics of jack mackerel, (Trachurus symmetricus), larvae. Fish Bull 76:403-414

Theilacker GH, Porter SM (1995) Condition of larval walleye pollock, Theragra chalcogramma, assessed with histological and shrinkage indices. Fish Bull 93:333-344

Tudela S, Palomera I, Quílez G (2002) Feeding of anchovy Engraulis encrasicolus larvae in the north-west Mediterranean. J Mar Biol Assoc UK 82:349-350

Uriarte I, Balbontín F (1987) Caracterización del estado de hambruna en las larvas de sardina Sardinops sagax musica (Pisces, clupeiformes), mediante criterios morfométricos e histológicos. Rev Biol Mar Valp 23:77-106

Watanabe Y (1985) Histological changes in the liver and intestine of freshwater goby larvae during short-term starvation. Bull Jpn Soc Sci Fish 51:707-710

Watanabe Y, Kuroki T (1997) Asymptotic growth trajectories of larval sardine Sardinops melanostictus in the coastal waters off western Japan. Mar Biol 127:369-378

Submitted: April 4, 2005; Accepted: August 5, 2005

Proofs received from author(s): December 20, 2005 